\title{
FORMATION OF MODERN MODEL OF BUDGET MANAGEMENT BASED ON METHODS OF PUBLIC ADMINISTRATION
}

\author{
Natalia Bernatska' \\ Ministry of Justice of Ukraine, Ukraine
}

\begin{abstract}
The review of scientific studies and publications confirms that in Ukraine, the interest of scientists in the theoretical and practical problems of budget management is growing. Domestic and foreign scientists have repeatedly drawn attention to the need for full and timely disclosure of the state of the formation and use of financial resources of society. The foreign experts studied foreign experience and grounded measures that could and should contribute to the achievement of the effectiveness of this process, the methods of ensuring transparency of the state budget and involving the public as the subject of control over the use of budgetary resources, in particular, public hearings, "e-government", are an area public administration. Budget management is an important instrument of state regulation of the activity of authorities. According to the analysis, one can see that today it is necessary to distinguish the following types of budget support as: informational, organizational, methodical, and regulatory. The state implements a policy of budgetary management with the help of management bodies. There is a close interconnection between representative, national, and operational management bodies. The principle of transparency of the budget system (in conjunction with its publicity) is enshrined in Article 7 of the Budget Code of Ukraine. An attention is drawn to the fact that the budget system as a "totality of the state budget and local budgets" is transparent by definition. It is fair to note that insufficient transparency of the budget process is not only a domestic problem. The Board of Directors of the IMF approved one of twelve internationally recognized financial standards - the Code of Good Practices on Fiscal Transparency. An assessment of the state of implementation of the principle of publicity and transparency in the budget management of Ukraine makes it possible to draw the following conclusions:

1. The content of the principle of publicity and transparency in the text of the Budget Code of Ukraine should be amended by formulating it as a principle of the budget process, while it is necessary to specify the ways of its practical implementation.

2. The full implementation of the principle of publicity and transparency of the budget process will increase the level of trust of citizens to the authorities of different levels, which is one of the factors of successful implementation of the state social and economic policy, and will deepen the democratic principles of the formation and development of Ukrainian society.

3. The lack of transparency of budget information at the planning stage significantly impairs the ability to manage budget resources, primarily at the local level, exacerbating the problem of full budget financing, especially at the end of the budget period.

4. Budget information for an overwhelming majority of stakeholders remains inaccessible, inaccurate, untimely, and incomplete in Ukraine, which led to a deterioration of Ukraine's position in the international rating by the Open Budget Index.

5. Improving the transparency of the budget process can be achieved through the use of the above measures. Their implementation will serve not only to improve the quality of the budget process and the effectiveness of budget management but also to establish harmonious social relations.

At the same time, the task of developing further directions of increasing publicity and transparency of the mechanism of functioning of the entire system of public finances in Ukraine remains relevant.
\end{abstract}

Key words: budget management, budget process, local budgets, transparency, Open Budget Index, public administration.

JEL Classification: H 530, H750, D730, M100

\footnotetext{
Corresponding author:

${ }^{1}$ First Deputy Minister of Justice of Ukraine, Ministry of Justice of Ukraine.

E-mail: nsevostianova@gmail.com
} 


\section{Introduction}

The development of democratic processes in Ukraine relates to various aspects of social life, including the functioning of its budgetary system. The financial resources accumulated by it, by definition, should be aimed at satisfying the needs of the entire society and its separate territorially determined components. However, insufficiently high, often unpredictable efficiency of the use of budgetary resources in Ukraine puts on the agenda the task of improving the functioning of the budget management system in general and improving the mechanism of action of its individual elements. One of such potentially effective measures is to ensure transparency of government decisions that are taken at some stage of planning and execution of the state budget. However, despite the passage of the budget system of Ukraine of different stages of its formation and development, the issue of the transparency of the budget process, unfortunately, remains relevant for the third decade (Demyanyuk, 2009; Prozorist byudzhetu, 2017).

The review of scientific studies and publications confirms that in Ukraine, the interest of scientists in the theoretical and practical problems of budget management is growing. Domestic and foreign scientists have repeatedly drawn attention to the need for full and timely disclosure of information on the state of the formation and use of financial resources of society (Yaroshevych, Shpak, Matviyishyn, 2012; Kyrylenko, 2015; Bulhakova, Baranovskyy, Kucher ta in., 2010).

Leading experts studied foreign experience and grounded measures that could and should contribute to the achievement of the effectiveness of this process, the methods of ensuring transparency of the state budget and involving the public as the subject of control over the use of budgetary resources, in particular, public hearings, "e-government", are an area public administration (Zhalilo, Moldovan, Shevchenko, 2010).

However, the relevant issues of forming a full-fledged mechanism for the disclosure of budget information remain unresolved. The difficult situation of the financial system of the state, as well as the peculiarities of the socio-political processes taking place in the country, exacerbate the problem of non-transparency of quantitative and qualitative characteristics of monetary flows that are administered by the bodies of national and local authorities in Ukraine. This requires the intensification of scientific research in the field of budget process and the appropriate justification of possibilities for expanding public access to budget information (Demyanyshyn Vasyl, 2008).

The author aims to deepen the content of the transparency of the budget process, to form an adaptive model of budget management using modern tools of public administration.

\section{The methodology of research}

Budget management is an important instrument of state regulation of the activity of authorities. At the same time, the effective organization of the budget control system promotes the realization of goals, timely detection and elimination of deviations, creates a motivation for the effective performance of its duties by state and local authorities, allows detecting negative trends in the management process in a timely manner, reducing the risk of occurrence of negative phenomena during the formation and use of financial resources of the budget, and also maintaining the efficiency of management of financial resources at an appropriate level.

The main objective of budget management is to ensure effective and efficient management of financial

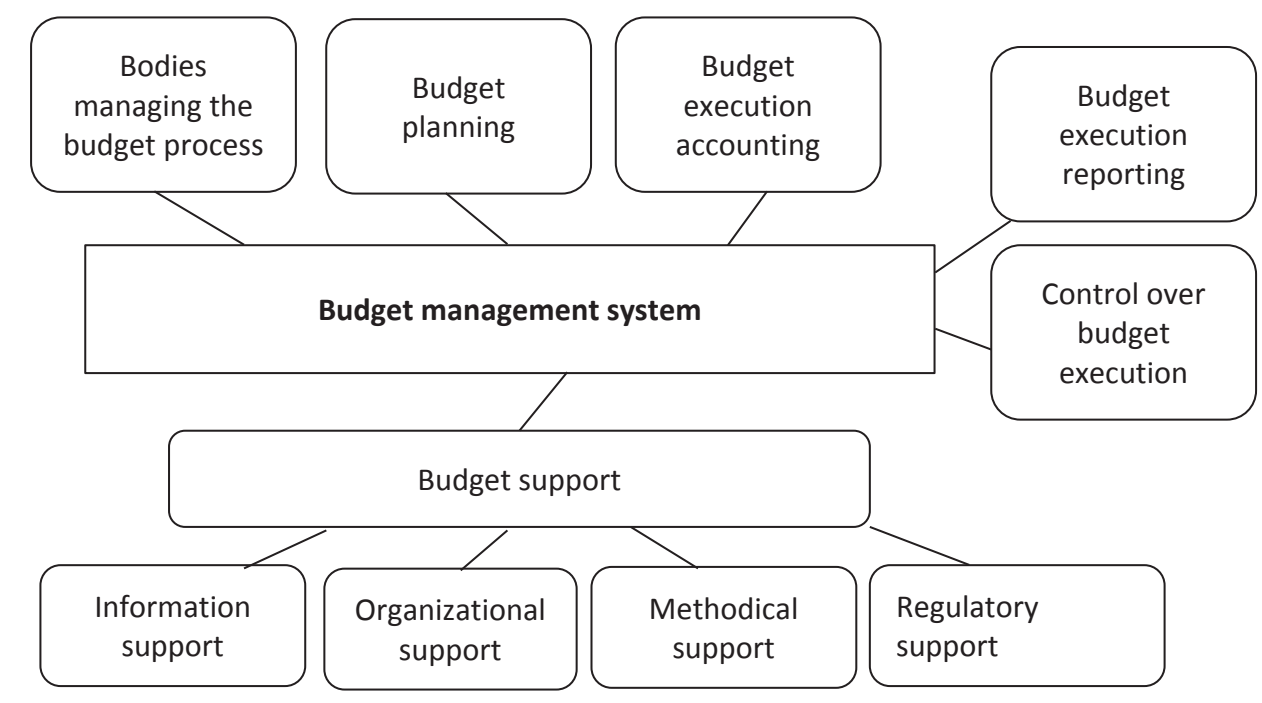

Fig. 1. Component model of budget management

Source: formed by the author 
resources in the budget sphere. Budget management is a fairly young industry of the economic science that is rapidly developing. It represents a complex, multilevel system (Fig. 1). In addition to the management bodies, the budget management system also includes other components: planning, accounting, reporting, control, and budget support (Fig. 1).

All of these components are closely interconnected in the budget process, each occupies a very important place, since the execution of the budget means to form its deficit-free part (to ensure the receipt of taxes and payments, in accordance with the current legislation), to effectively finance the expenditures approved in the budget, provide effective management of financial resources in the budget sphere (Babych, 2011).

Extremely important is the budget support that enables to regulate relations of providing the population with the necessary set of knowledge on the formation and use of financial resources of budgets of different levels.

In accordance with Fig. 1, it can be seen that today it is necessary to distinguish the following types of budget support as: informational, organizational, methodical, and regulatory.

Information provision provides a meaningful, reliable, and operational information base, which serves as the basis for making optimal managerial decisions regarding the use of budget funds by authorized bodies.

Organizational support involves the creation (improvement) of existing and ensuring the effective functioning of individual elements of the organizational system of the budget management, as well as an organizational mechanism for managing budget funds or their aggregate in general in accordance with the chosen strategies in such a way that these organizational elements of the system act as elements of strategic development of the country in general.

Methodical support - a set of documents of organizational, organizational and methodological, organizational and administrative, technical, technical and economic, and economic nature, as well as reference materials and other documents approved by the authorities in accordance with the established procedure for the efficient and targeted use of budget funds.

Regulatory support is a type of support that includes laws and regulations that regulate fiscal relations in Ukraine and helps to find ways to improve existing and emerging new legal regulations necessary for fundamentally new tasks in the field of budget management. Among the most important legislative acts, the Budget Code of Ukraine occupies a special place, which in a complex combines and regulates all stages of the budget process and defines the general principles of management of financial resources.

As can be seen from Fig. 1, the state implements a policy of budgetary management with the help of management bodies. There is a close interconnection between representative, national, and operational management bodies. So, the Verkhovna Rada of Ukraine

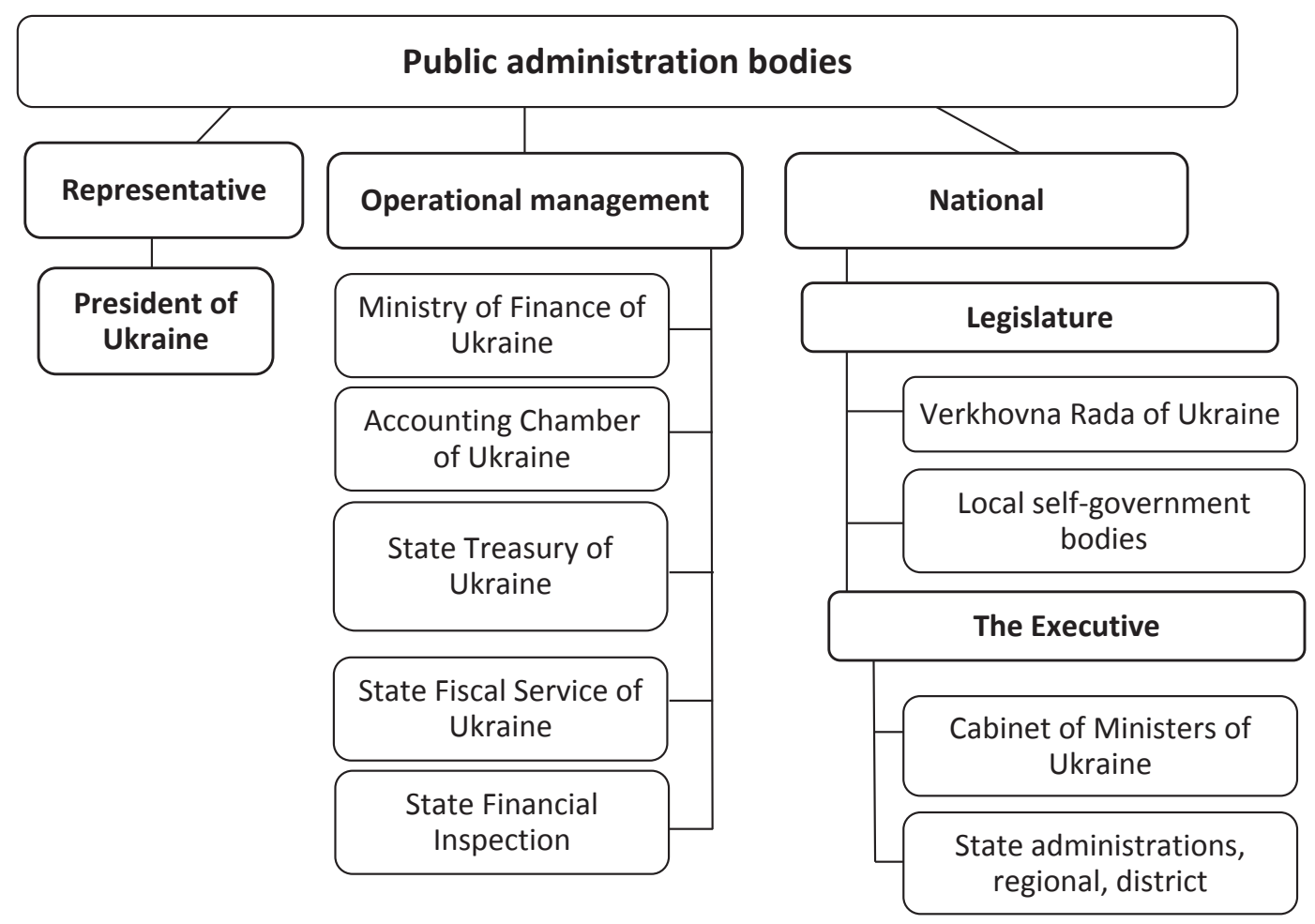

Fig. 2. The organizational structure of budget management 
adopts the law of Ukraine on State Budget for the current year, the President of Ukraine signs laws and decrees. In turn, the Cabinet of Ministers of Ukraine ensures the implementation of the budget of Ukraine, and the Ministry of Finance of Ukraine conducts the general organization and management of the execution of the state budget, coordinates activities of the participants in the budget process (Blishchuk, 2011).

We believe that depending on the role and functions, it is worthwhile to distinguish three groups of bodies that carry out budget management (Figure 2): representative; national; operational management bodies.

To date, each management system, including the budget one, consists of two interrelated parts - the object and the subject of management.

The object of budget management is the state and local budgets, and the subject - the system of representative, legislative, and executive authorities, which are endowed with the respective rights and powers in the field of budget process management.

Each part plays an extremely important role. Without an object, the process of managing financial resources in the budget sphere is impossible. And the activity of subjects of management determines the quality and effectiveness of budget management.

Management of public finances is not an end in itself but serves as a mandatory element of the regulatory system, the purpose of which is to identify in a timely manner deviations from accepted standards, violations of the principles of legality, efficiency, expediency, which would allow to make appropriate corrections on a case-by-case basis, strengthen the responsibility of authorized persons, get damages and prevent or, at least, complicate the recurrence of detected violations in the future (Khomutenko, Baranova, Dubovyk, 2014).

\section{Results and discussion}

On the basis of the generalization of the above definitions, it is possible to propose definitions of budgetary management as a system for the development and implementation of managerial decisions in the process of formation and use of centralized cash resources (funds) of the state and its territorial and administrative units. Budget management includes budget forecasting, planning, justification of the draft budget of different levels, consideration of submitted projects, their revision, approval, amendments to approved budgets, budget execution, monitoring, analysis, reporting. In the process of budget management, there is formation (design, review, and approval) and budget execution, control of budget discipline, as well as preparation, consideration, and approval of the report on execution.

It is important to understand that the budget, as the main financial document of the state or a certain territorial entity, must meet certain criteria (that is, contain legally established parameters). L.I. Didkivska and L.S. Holovko determine the following main parameters of the budget: absolute size; the share of GDP reallocated through the budget; volume and structure of funding sources; volume and structure of budget expenditures; the ratio of revenues and expenditures of the state (Kovalchuk, Kozenkov, Kozenkova, Yakubova, 2011). It should be noted that the budget is a lever of the influence of the state on various aspects of the economic life of society, that is, it acts as a means of economic regulation. With the help of budgetary levers, the income of the population and the corporate sector, inflation, employment, and consumer activity can be regulated. Experts point to significant budget opportunities in implementing state investment and innovation-technology policy. In a modern economy, the budget is one of the main instruments of the state apparatus for the conduct of state policy (primarily in the socio-economic sphere). Thereat, the following levers of fiscal policy are used: taxes, fees, expenditures financing, budget deficits, budget debt, etc. The process of forming budget revenues and expenditures is inextricably linked with the main results of the economic development of the state or its regions, as well as subjects of budget legal relations - taxpayers, managers of budget funds, etc. Organization of budget management in the country depends on many factors: political structure, management traditions, peculiarities of economic and financial development, chosen fiscal policy, etc. Before science, the question arose about the generalization of budget management models, which should be based on certain general principles. "The ideal model of fiscal management, - as rightly stated, -presupposes compliance with the rules for the formation and implementation of the budget on the basis of commonly accepted principles that are in line with the values of a democratic and ruleof-law state, civil society, market economy (Boyarko, Dekhtyar, Deyneka, 2012). These principles, formed in the course of the evolution of financial theory and practice, as the basis for the construction of the budget and the organization of the budget process, include the completeness, unity, and periodicity of the budget, its reality, transparency, and openness" (Demyanyuk, 2009). It is clear that these principles can (and should) be implemented precisely in the process of budget management, that is, the implementation of certain management procedures.

The principle of transparency of the budget system (in conjunction with its publicity) is enshrined in Article 7 of the Budget Code of Ukraine. The fact draws attention that the budget system as a "totality of the state budget and local budgets" (para 2.1.5. of the Budget Code of Ukraine) is transparent already by definition (Stepanova, 2015). 
The content of the State Budget and local budgets is obvious; the composition of the latter is clearly regulated by law (para 2.1.34 of the Budget Code of Ukraine). At the same time, there are no differences in the treatment of the State Budget and local budgets, which are fixed by provisions of the financial theory, and their implementation in practice (as is often the case in domestic realities). Therefore, the author believes that the content of the legislatively defined principle of publicity and transparency concerns not the general budget system of the country, that is, immobilized indicators of income and expenditure part of budgets of different levels, their financing, but those decisions and measures that led to the emergence of such indicators. This is precisely about the budget process - an activity involving various actors - "organizations, institutions, and officials with budgetary powers" (para 19.3 of the Budget Code of Ukraine). In this regard, it is advisable to support the proposal of domestic scientists to clarify the place, as well as ways to implement the principle of publicity and transparency in the budgetary sphere on the above principles (Yaremenka, 2016; Zhalilo, Moldovan, Shevchenko, 2010; Frolov, 2018).

The content of clarity (transparency - in foreign terminology) in the budget process needs a deeper understanding. Note that specialists in the state budget used and use different terms, which include informing the public, voters about the planned and actual state of the main financial plan of the state, namely: publicity, transparency, and truthfulness. The last two terms indicate that "all revenue and all expenses, without any futile concealment or secret definitions, should be indicated in the budget" (Frolov, 2018).

Such an interpretation of the transparency of the state budget raises the issue of its degree. Naturally, it is precisely the requirements of ensuring state security that is the determining criterion of the limit, to which information about incoming and outgoing flows of budget resources should be disclosed to the public. Such an approach is found in Article 31 of the Budget Code of Ukraine "Secret Expenditures". At the same time, the content of the latter, envisaged for the activities of state authorities, in the interests of national security, their potentially possible structure, and size are not defined by law.

This allows the central authorities to manipulate budget indicators in certain political and economic circumstances, artificially narrowing public access to relevant data, primarily about the use of public funds.

Contrary to the above, the concept of "secret expenditures", regulated by law, does not apply to local budgets, which in fact should mean full and timely disclosure of budget information by local selfgovernment bodies and executive bodies at the local level. However, in many cases, if there is a desire to be informed about the state of income and expenditure of local budgets, there are artificial barriers, up to the appearance of administrative indications regarding the metered provision of information on budget indicators.

In addition, not only the volume (quantity) but also the quality of the latter often generates more questions than answers to them. Thus, the indicators of the State Budget and local budgets, as a rule, are presented in aggregate, without proper detail and specification on the sources of income and the purposeful allocation of budgetary resources. At the same time, revenue budget information, which would be measured on a scale at least up to 1,0 thousand $\mathrm{UAH}$, is practically inaccessible. Of course, for a financial plan, the balance of which is measured by hundreds of billions of hryvnias, the figure of one or even ten thousand hryvnias is negligible. But such sums reflect financing of not just a separate branch of the national economy or a manager of budgetary funds (that is, one or another budgetary institution). In the end, both the recipients of budget resources and their real producers are specific citizens (objectively, taxpayers), the size of their many needs is often measured by these indicators.

In many developed countries, the situation is the opposite. For example, in Germany, the "price of a line", that is, the requirement to detail articles of the state budget in amounts is 10 euros. Therefore, German citizens know how the state budget is being formed and what almost every euro is used for (Mykhaylenko, 2010). Unlike them, our fellow citizens have to confine themselves to inadequate budget information. Its low quality is also determined by the fact that the public administration of various levels reveals, as a rule, its own achievements, that is, the positive results of the implementation of budget policy.

Of course, first of all, such data are a reflection of the overall effectiveness of authorities. However, the one-sided presentation of financial, including budget information, on the one hand, is in fact half-truth, on the other hand, does not allow society to respond adequately to the various challenges and threats that are the result of the crisis conditions of the development of the national economy.

In general, there are additional grounds for an extremely critical (often novolescent) assessment of actions of government structures, instead of proper understanding and acceptance of anti-crisis socioeconomic measures (painful - in the short term, but productive - over a longer period of time). We believe that knowledge of the real state of affairs in the national economy and the corresponding readiness of society to overcome financial difficulties can become one of the factors of the potential increase of the effectiveness of the state social and economic policy and its budgetary vector. Indeed, this approach is likely to maintain a high level of public confidence in the authorities, which is an important factor in the successful implementation of their financial policy, above all. 
Unfortunately, today in Ukraine, there is a low level of institutional trust in such constituents as the state (government and local authorities) and business, while mass media with a high level of trust are often controlled by the state, business or their interrelated oligarchic noninstitutional associations, their irresponsible behaviour in relation to the future is not ruled out, which will lead to a recurrence of the crisis, as well as the inappropriate use of natural and social resources through deception (Zaychykova, 2014). This creates a closed circle of negative phenomena, which lead to the failure to fulfil their functions as budgetary management, so the administrative direction of public servants - public administration (Fig. 3).

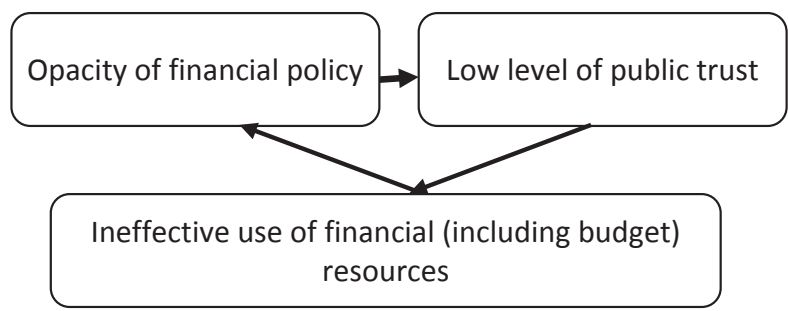

Fig. 3. Creating a range of negative phenomena of budget management and public administration

Source: formed by the author

Particularly, the influence of the factor of trust increases at the territorial level, where the connections between the community members (institutions, voters, administrative apparatus) are significantly stronger than at the state level and, accordingly, at the level of national government bodies. Therefore, confidence in, first of all, mechanisms for using financial resources of the territory, in which local self-government bodies are involved, potentially creates additional opportunities and incentives for direct donors of such funds taxpayers - to participate in the formation of these resources in the future.

On the other hand, the opacity of the budget process, especially at the local level, is one of the obstacles to, for example, investment activities of local governments, as well as their borrowings to local budgets (recall, the Budget Code of Ukraine provides such a possibility only for the development budget, in others words, primarily for the purpose of investing). After all, any creditor (whether it represents a purely banking sector of the country or an investor in the securities market) needs to minimize the risks of placing its own financial resources.

It is to a large extent ensured by the borrower (in our case, a local government), which, among other things, provides for obtaining detailed information on the state of local finances and, in particular, local budgets in the respective territory. In this regard, we note that the principle of transparency implies the disclosure of various components of budget information (indicators of income, expenditure and lending, budget financing), not only on the basis of the results obtained but also on all other stages of the budget process. Thus, the executive bodies of the state as a whole comply with Articles 58-62, 80 of the Budget Code of Ukraine, forming and publishing reports on the implementation of the State Budget of Ukraine and local budgets. However, the socio-economic indicators that serve as the starting point for planning the indicators of the respective budgets are absolutely inadequate, obscure, inaccessible, and in most cases inaccessible.

This is particularly relevant in the context of the actual cessation of fiscal decentralization policies and narrowing the scope of local self-government in Ukraine, when not that ordinary voters but also local financiers, lack information on the origin of certain numerical data verified by the government from the Ministry of Ukraine's finances as budgetary benchmarks. This situation leads to the ineffectiveness of managing budget resources at the local level throughout the entire budget period: the need for constant changes and additions to budget indicators, permanent search for new sources of income, lobbying central government decisions on providing additional subsidies and subventions, etc.

Particularly significant for taxpayer citizens is administrative pressure on budget funds managers to increase their income from a special fund, which often takes the form of charitable contributions, that is, seizures from individual or family income of consumers of services of such budgetary institutions. For example, in the Odesa region, the indicator of the plan implementation for such own revenues of budget institutions as charitable contributions, in 2014, was executed by $353.7 \%$, and in 2016 - by $490.7 \%$. At the same time, their share in own revenues of spending units exceeded $35.0 \%$. The increase in the weight of own revenues of budget institutions in Ukraine as a whole is reflected in Figures 4 and 5.

During January-December 2017, the revenues to the general fund of local budgets of Ukraine (excluding intergovernmental transfers) amounted to 192.0 billion UAH, which is higher than the Ministry of Finance's estimated figures by 21.3 billion UAH. Compared to 2016 , revenues grew by 45.4 billion $\mathrm{UAH}$ or by $+31 \%$.

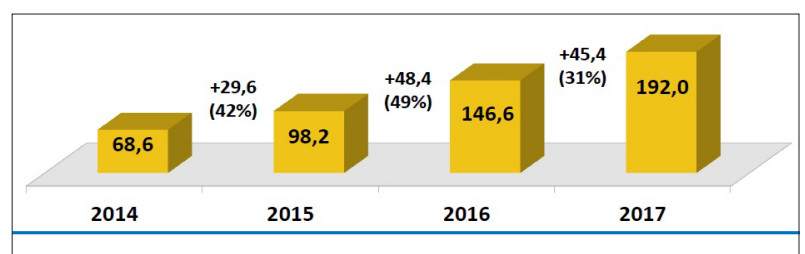

Fig. 4. Own revenues of local budgets (billion UAH) for 2014-2017

Source: formed on the basis of Mistsevi byudzhety: eksperty pidbyly pershi pidsumky 2017 roku

This indicates an increase in the interest of local self-government bodies in increasing revenues to 
local budgets, implementing measures to find reserves for their filling and improving the efficiency of administration of taxes and fees. The share of financial resources receiving local budgets from the state budget reaches $50 \%$, that is, local authorities have a half of the financial resources of the consolidated budget.

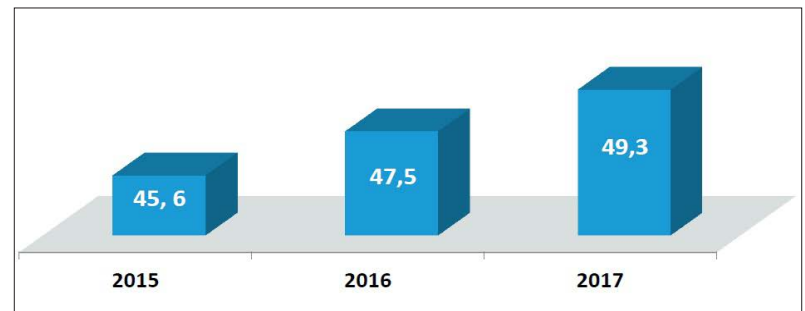

Fig. 5. The share of local budgets (with transfers) in the consolidated budget of Ukraine (\%)

Source: formed on the basis of Mistsevi byudzhety: eksperty pidbyly pershi pidsumky 2017 roku

The share of local budgets in the consolidated budget reaches $50 \%$, that is, local authorities have a significant financial resource to effectively manage and direct them for community development (in relations with the state $-50 / 50)$.

Such growth rates of local budget revenues are attributable to government actions aimed at financial decentralization. New conditions have raised the interest of local self-government bodies to increase revenues to local budgets, to take measures to find reserves for their filling, and to increase the efficiency of administering taxes and fees.

In addition, today, local self-government gradually departs from the previously existing consumer position. Today, they are replacing the expectations of subsidies by active actions in creating an effective management apparatus, directing funds for community development, analysing the spending of budget funds, and preventing instances of their inefficient, irrational use.

It is fair to note that insufficient transparency of the budget process is not only a domestic problem. The Board of Directors of the IMF approved one of twelve internationally recognized financial standards - the Code of Good Practices on Fiscal Transparency (Indeks vidkrytosti byudzhetu 2012-2016).

Taking into account its provisions, the International Budget Partnership, established in 1997, initiated an assessment of the Open Budget Index. It determines whether the government provides public access to eight major budget documents and whether they are clear, timely, and useful. These documents are a budget declaration, draft budget, budget, budget for citizens, quarterly reports on budget execution, semi-annual report, annual report, and audit report. According to the Open Budget Index in 2016, Ukraine has occupied a rather high 19th place in a sample of 94 countries. At the same time, it outpaced all other CIS countries and Georgia, as well as some of the member countries of the European Union. Ukraine's score increased from 55 points in 2008 to 62 points in 2016, largely due to the publication of information on the draft budget (Indeks vidkrytosti byudzhetu 2012-2016).

In addition, as noted in the review, the government of Ukraine published during the year budget reports that meet international standards (Indeks vidkrytosti byudzhetu 2012-2016). However, according to a similar assessment in 2012, Ukraine ranked 35th among 100 countries, having received 54 points out of 100 possible. This figure turned out to be higher than the average score of 43 points for all the countries under study but lower than the neighbouring countries, in particular, Bulgaria, Poland, Russia, Slovakia, and the Czech Republic.

The main claim of the International Budget Partnership to Ukraine is the lack of a so-called civil budget, that is, the government's explanations for articles on income and expenses in a clear form. The concept of a "civil budget" is associated with the fact that its main conceptual provisions are formed as a result of the active participation of individuals and independent nongovernmental organizations through broad discussion and provision of appropriate proposals or comments.

The final version of the draft civil budget is presented on the Internet in a generalized way to ensure a simple perception of its content by a broad general population of the country. The method of formation and focus on public awareness determine the corresponding name of such a version of the budget - "civil budget" (Frolov, 2018). As we can see, ensuring a high level of transparency of the budget process is directly linked to the formation of a real, and not declared, civil society in Ukraine. Public hearings on budgetary or tax issues, organized by both central and local authorities, have been repeatedly criticized by specialists.

However, the problem of activating the civic initiative in the budget process, the development of its forms and methods requires additional scientific research. The revealed difficulties in ensuring the publicity and transparency of the budget process objectively require the adoption of effective measures aimed at overcoming them. In January 2011, the Cabinet of Ministers of Ukraine prepared a draft Concept of the State Target Program for Creation and Development of the Integrated Information and Analytical System "Transparent Budget", the fifth (last) stage of implementation of which provided for its final term for the second quarter of 2013 (Concept of the State Target Program, 2013).

Unfortunately, the concept remained the project. Such a participation, probably, also awaits the draft law "On Openness of the Use of Public Funds", introduced to the Verkhovna Rada of Ukraine by a group of people's deputies in May 2013 (Concept of the State Target Program, 2013). In addition, the implementation of such legislative and regulatory documents requires, as their 
authors have predicted, proper financial and material security. Thus, the financing of activities related to the creation and development of an integrated information and analytical system "Transparent Budget" provided for by the aforementioned concept required 50.0 million UAH (at current prices of 2011) (Mistsevi byudzhety: eksperty pidbyly pershi pidsumky, 2017).

According to calculations of the authors of the draft, its implementation is estimated at 0.5 million $\mathrm{UAH}$ at the stage of development and testing, and it was planned to spend 3.0 million UAH annually for the maintenance of the web-portal. Of course, an increased level of control over public funds would help to compensate for planned expenditures by additional revenues to the state budget.

For example, according to expert estimates, it would be possible to use 30-40 billion UAH more effectively in the field of public procurement (Indeks vidkrytosti byudzhetu 2012-2016). However, in the context of the crisis of the domestic system of public finances, the permanent deficit of the state budget to find an additional resource for these legislative innovations, of course, it is extremely difficult. This explains why initiatives to improve the transparency of the budget process in Ukraine tend to remain initiatives. It is therefore advisable to pay attention to those proposals that, according to the calculations of the International Centre for Policy Studies, practically do not require significant additional costs for the implementation of the necessary measures, namely:

- publish an annual report, which is currently being prepared only for internal use;

- make and publish a budget for citizens;

- include a detailed description of the macroeconomic and fiscal environment in the current state budget;

- submit the data in the draft state budget:

1) about the actual expenditures for the previous year, in particular, by individual programs, as well as the planned expenditures by economic and departmental classification;

2) about the non-tax revenues of the budget and the state debt for the past fiscal year;

3) on the impact of various macroeconomic assumptions on budget execution;

4) about the relationship of the budget with the declared government objectives of the policy and performance indicators of budget programs;

5 ) on the use of extrabudgetary funds in both financial and in-kind form (in particular, regarding sources of donor assistance);

- include information at the program level in the current budget;

- to provide information on the structure of public debt in the report on budget execution throughout the year; - in the annual reports, explain the difference between the planned and actual level of expenditures;
- in the audit reports on the budget, provide information on the actions that the executive authority conducts to implement the audit recommendations.

Expanding the list of mandatory disclosure of budget information, such as the inclusion of planned calculations of indicators of the main items of income and expenditure, is absolutely possible in the current informational environment, which involves simplifying the mechanisms of communication through the use of technical means.

\section{Conclusions}

Thus, today's budget management can be considered as: the science of management; a budget management system that is represented by a combination of two elements - objects and subjects of management; art that "arm" managers with specific tools in the budget sphere; one of the areas of financial management; multi-level system of budget process management. However, in our opinion, it is expedient to consider that this is a set of interrelated functions, principles, methods, techniques, and procedures used by the authorized authorities.

Using all the components of budget management, the state plans and manages the key budget indicators, which allows taking into account the budget's ability to influence sustained economic dynamics, employment, investment, innovation, and equalization of regional development. Budget management is aimed at ensuring the effective implementation of the procedures for the drafting, review, approval, and execution of the budget to achieve economic and social benefits in terms of the changing environment.

Understanding the essence of the budget and other public financial resources as public funds objectively makes it possible to have information about their state (formation, distribution, and use) by any citizen of the country, especially if he or she is also a taxpayer at the same time.

Assessment of the state of implementation of the principle of publicity and transparency in the budget management of Ukraine makes it possible to draw the following conclusions:

1. The content of the principle of publicity and transparency in the text of the Budget Code of Ukraine should be amended by formulating it as a principle of the budget process, rather than the principle of the budgetary system of Ukraine; herewith it is necessary to specify the methods of its practical implementation.

2. The full implementation of the principle of publicity and transparency of the budget process will contribute to increasing the level of trust of citizens to the authorities of different levels, which is one of the factors of successful implementation of the state social and economic policy, and will deepen the democratic principles of the formation and development of Ukrainian society. 
3. The lack of transparency of budget information at the planning stage significantly impairs the ability to manage budget resources, primarily at the local level, exacerbating the problem of full budget financing, especially at the end of the budget period.

4. Budget information for an overwhelming majority of stakeholders remains inaccessible, inaccurate, untimely, and incomplete in Ukraine, which led to a deterioration of Ukraine's position in the international rating by the Open Budget Index.
5. Improving the transparency of the budget process can be achieved through the use of the above measures. Their implementation will serve not only to improve the quality of the budget process and the effectiveness of budget management but also to establish harmonious social relations.

At the same time, the task of developing further directions of increasing publicity and transparency of the mechanism of functioning of the entire system of public finances in Ukraine remains relevant.

\section{References:}

Babych T. S. (2011). Makrofinansove biudzhetuvannia: navch. posib. [Macrofinancing Budgeting: Teach. Manual]. Kyiv: KNEU.

Blishchuk K. M. (2011). Derzhavni ta mistsevi finansy. Byudzhetnyy protses: navch. posib. [ State and local finances. Budget process: teach. Manual]. - 2nd form., Reworked. and complemented - Lviv: Naukova knyha.

Boyarko I. M. Dekhtyar N. A., Deyneka O. V. (2012). Efektyvnist finansiv derzhavnoho sektoru ekonomiky $\mathrm{v}$ systemi upravlinnya sotsialno-ekonomichnym rozvytkom Ukrayiny: monohr. [The efficiency of public sector finance in the system of social and economic development of Ukraine: monogr.]. Sumy: Univ. book

Bulhakova S. O., Baranovskyy O. I., Kucher H. V. ta in (2010). Byudzhetna systema Ukrayiny ta Yevrosoyuzu: monohrafiya [Budget system of Ukraine and the European Union: monograph]. Kyiv: KNTEU.

Code of Good Practices on Fiscal Transparency (2017). - Retrieved from: http://www.imf.org/external/np/fad/ trans/code.htm

Demyanyshyn Vasyl (2008).Kontseptualni zasady vydatkiv byudzhetiv ta yikh rozpodil mizh lankamy byudzhetnoyi systemy [Conceptual framework of budget expenditures and their distribution between the links of the budget system] Vestnik TNEU, No 3, pp. 2-77.

Demyanyuk A.V. (2009). Zabezpechennya prozorosti byudzhetnoho protsesu na mistsevomu rivni [Ensuring transparency of the budget process at the local level]. Ternopil: Economic Thought.

Frolov S.M. (2018). Doslidzhennya problem orhanizatsiyi i realizatsiyi byudzhetnoho protsesu v Ukrayini [Research on the organization and implementation of the budget process in Ukraine]. Retrieved from: http://essuir.sumdu.edu.ua/bitstream/123456789/8043/3/a.r.9.pdf

Indeks vidkrytosti byudzhetu 2012-2016: Ukrayina vtrachaye pozytsiyi $\mathrm{v}$ mizhnarodnomu reytynhu [The index of budget openness for 2012-2016: Ukraine loses its position in the international rating] Retrieved from: http://icps.com.ua / / key_issues/econ_analysis/indekc-vidkritocti-bjudzhetu\%E2\%80\%932012-ukrajinavtrachaje-pozitsiji-v-mizhnarodnomu-rejtinhu.html

Khomutenko V.P., Baranova V.H., Dubovyk O.Y. (2014). Byudzhetna systema: Navchalnyy posibnyk [Budget system: Textbook]. Odessa: Barteneva Publishing House.

Kontseptsiya Derzhavnoyi tsilovoyi prohramy stvorennya ta rozvytku intehrovanoyi informatsiyno-analitychnoyi systemy «Prozoryy byudzhet» [Concept of the State Target Program for Creation and Development of the Integrated Information and Analytical System "Transparent Budget"] (2013). Retrieved from: http://www.minfin.gov.ua/control/uk/publish/article? art_id=283476\&cat_id =283464

Kovalchuk K. F., Kozenkov D. Ye., Kozenkova N. P., Yakubova S. P.(2011). Byudzhetnyy menedzhment: navch. posib. [Budget Management: Teach. Manual]. Dnipropetrovsk: A New Ideology.

Kyrylenko O.P. (2015). Detsentralizatsiya byudzhetnoyi systemy Ukrayiny v umovakh formuvannya vidkrytoho suspilstva [Decentralization of the budgetary system of Ukraine in the conditions of formation of an open society]. Ternopil: Economic Thought.

Mistsevi byudzhety: eksperty pidbyly pershi pidsumky 2017 roku [Local budgets: experts summed up the first 2017 results]. Retrieved from: http://www. http://decentralization.gov.ua/news/8053

Mykhaylenko S.V. (2010). Byudzhetnyy menedzhment: stan ta otsinka efektyvnosti [Budget Management: State and Performance Evaluation]: monohraf. Odessa: VMV, Printing South.

Prozorist byudzhetu 92017). Zaluchennya hromadskosti - Instytut byudzhetu ta sotsialno-ekonomichnykh doslidzhen [Transparency of the budget. Public Involvement - Institute for Budget and Socio-Economic Research]. Retrieved from: http://www.ibser.org.ua/.../модумь\%2017\%20ібсеА.pdf

Stepanova A.M. (2015). Byudzhetne rehulyuvannya v umovakh instytutsiynykh peretvoren [Budgetary regulation in the context of institutional reforms]. «Molodyy vchenyy» "Young Scientist", no2(17), pp. 25-28.

Vlasyuk N. I., Medinskaya T. V., Melnyk M. I. (2011). Mistsevi finansy: navch. posib. [Local Finances: Teach. Manual]. Kyiv: Alerta.

Yaremenka O. L. (2016). Mistsevi byudzhety v umovakh kryzovykh yavyshch i reformuvannya: (monohrafiya) [Local budgets in the context of crisis phenomena and reform: monograph)]. Kherson: KHIF UDUFMT, 
Yaroshevych N. B., Shpak N. O., Matviyishyn V. YE. (2012). Byudzhetnyy menedzhment [Budget Management]. Lviv: Lviv Polytechnic Publishing House.

Yuriya S. I., Demyanyshyna V.H., Kyrylenko O. P. (2013). Byudzhetna systema: pidruch. [Budget system: subhead]. Ternopil: TNEU.

Zaychykova V.V (2014). Funktsiyi mistsevykh finansovykh orhaniv v umovakh byudzhetnoyi reform [Functions of local financial institutions under the conditions of budget reform]. Finansy Ukrayiny. - Finances of Ukraine. No 6, pp. 72-79.

Zhalilo YA. A., Moldovan O. O., Shevchenko O. V.; za red. YA. A. Zhalila (2010). Nova arkhitektura byudzhetnoyi systemy Ukrayiny: ryzyky ta mozhlyvosti dlya ekonomichnoho zrostannya [The New Architecture of Ukraine's Budget System: Risks and Opportunities for Economic Growth]. Kyiv: NISD/NISS. 